\title{
Analyzing multi-stakeholder collaborative governance practices in urban water projects in Addis Ababa City: procedures, priorities, and structures
}

\author{
Wassihun Gebreegiziaber Woldesenbet ${ }^{1}$ (D)
}

Received: 20 July 2018 / Accepted: 27 December 2019 / Published online: 3 January 2020

(c) The Author(s) 2020

\begin{abstract}
Though different technical approaches have been applied, Addis Ababa water bodies are persistently facing problems that affect their biological, economic, sociological, and ecological assets. To fill the technical gaps, multi-stakeholder collaborative governance approaches are unfolding, in the academia, as the important tools or methods of dealing with water problems. Thus, the basic objective of this qualitative exploratory study is analyzing the processes and outcomes of multistakeholder collaboration structures on the governance of urban water projects, and developing potential pathways of building collaboration among stakeholders for the governance of water bodies. The results of this study show that the processes of multi-stakeholder dialogues are handicapped by the absence of prehistory of collaborations, asymmetrical pre-deliberation communication, and the representation of stakeholders by individuals with no experience or the required expertise, and the lack of willingness among stakeholders to engage in the process of dialogues. The activities of supervision, evaluation, river assessment programs, and the establishment of stable and secured governance frameworks are loaded in a few government sectors, leading to the eruption of multiple problems. On the other hand, the potential pathways of building strong collaboration among stakeholders require a systematic procedure that establishes legal, political, and administrative commonality among stakeholders. This guides to instill responsibility, ownership, and commitment on the leaders, directors, and experts to work with others. The study concludes that urban water problems could not be well addressed unless the governance structures are built in advance by making the pre-deliberation and deliberation processes that combine the principles of simplicity, symmetrical communication with all stakeholders, the appointment of experts, and the development of a regular collaboration system. Further, these would enable to govern water governance projects effectively by combining the ecological, social, political, and economic perspectives. Besides, considering cultural, legal, social, and political contexts and establishing individual and organization sensitive committees at various levels is crucial for sustainability and adaptability.
\end{abstract}

Keywords Water · Urban water problems · Collaborative governance $\cdot$ Multi-stakeholder collaboration · Governance

\section{Introduction}

The technical approaches of dealing with urban water problems now appear to become medieval in the contemporary period in which water problems are becoming more societal and cross-boundary (Holt et al. 2012). Henceforth, multistakeholder approaches are newly emerging governance

Wassihun Gebreegiziaber Woldesenbet zemahbereyordanos@gmail.com; wassihun.egziabher@wku.edu.et

1 Regional and Local Development Studies, Wolkite University, Wolkite, Ethiopia approaches in the area of natural resources, including urban water resources. They, quintessentially sustainable approaches (Azadi et al. 2011), are broad and comprehensive ways of dealing with urban water problems which arise out of multiple factors, lack of a collaborative structure being the prominent one (Harrington 2017; Opperman et al. 2009; Huntjens et al. 2015). Therefore, the procedures, priorities, and structures of multi-stakeholder collaboration in the governance of urban water resources are now the concerns that have to be investigated and understood for a strong and effective means of dealing with urban water problems sustainably and deeply.

Addis Ababa water resources are facing many problems that affect their biological, ecological, sociological, and 
economic aspects (Meklit et al. 2017). Although Addis Ababa water bodies are suffering from a variety of problems and are making the population vulnerable to various risks, the approaches of dealing with such problems are ineffective and unsustainable (Meklit et al. 2017). Weak multi-stakeholder collaboration is the prominent waterrelated problem in Addis Ababa City among a multiplicity of concerns, such as industrial, household, institutional, and pollution-induced problems (Environmental Protection Authority of Addis Ababa City 2008). Different stakeholders, including different government organizations, hotels, factories, households, community-based organizations, and other civic societies are responsible to stand at the forefront in addressing water problems. However, though the Environmental Protection Authority of Addis Ababa City and Addis Ababa Rivers Riversides Climate Change Adaptation Project Office (AARRCCAPO) are trying to mobilize various stakeholders, the level of collaboration is staggeringly weak (Meklit et al. 2017; Leta et al. 2016). While several government sectors are involved in collaborative governance forums and systems, other stakeholders are on the other backdoor, compounding and worsening water problems (Environmental Protection Authority of Addis Ababa City 2017; Meklit et al. 2017; Woldesenbet 2018). Therefore, it is now an existing reality that the issues of procedures of collaboration, priorities, and structures of collaborative governance activities among various stakeholders are poorly architected and designed. There is a dearth of study that analyzed such affairs in an organized and systematic manner from various contexts.

This study examines the practice of multi-stakeholder collaborative governance of urban water projects in Addis Ababa City. To achieve this objective, this study focuses on the following issues.

1. To examine the processes and outcomes of multi-stakeholder collaborative water governance activities.

2. To identify potential pathways of improving the collaboration of various stakeholders in collaboratively governing water projects in Addis Ababa City.

\section{Theoretical frameworks: power, procedures, priorities, and structures}

Given that the policy proposals of government officials are becoming much contested by other non-state actors, multistakeholder collaborations among government, private actors, civil society organizations, and community-based organizations are entering into the limelight as a formidable banks of courting effective procedures, priorities, and structures to address water affairs (Organization for Economic Cooperation and Development (OECD) 2015; Megdal and Eden 2017). Ansell and Gash (2007) argued, in their collaborative governance model, the various collaborative discussion processes as being represented by various elements. Before the establishment of a discussion forum, the pre-deliberation communication platform is the key to the mutual recognition of common problems and the development of a sense of responsibility (Ansell and Gash 2007; Emerson et al. 2011). Thus, a shared understanding that is demonstrated by the existence of common mission, principles, and values is the key to develop intermediate outcomes which in turn lead to the establishment of face-to-face dialogues and discussions. The framework adopted is shown in Fig. 3.

Harrington (2017) expressed that mutual discussions and understanding of water problems are the keys to the institutionalization of discernible water governance tasks. The deliberation stage of multi-stakeholder collaborative governance processes entails the building up of common understandings among the participants as an avenue to create sustainable mechanisms of addressing water problems and to ultimately reach out agreements and develop social learning (Morse and Stephens 2006). Hard conversations, constructive self-assertion, exchange of new questions, entertainment of disagreements, and development of ulterior points of common understandings are important elements of deliberation (Emerson et al. 2011).

The implementation phase of multi-stakeholder governance structures is an important part of the collaborative frameworks to bring out fundamental and on-ground changes to the mutually felt problems. Multi-stakeholder governance should generate the new and more fundamental capacity to accomplish a common purpose; and it also entails that the entire stakeholders should come to combine their unique resources to create the potential for joint action (Emerson et al. 2011; Porten 2013). This stage includes establishing common steering committees, monitoring agreements, evaluating outcomes, or otherwise managing the partnership processes (Morse and Stephens 2006).

The dynamics of collaborative governance, involving pre-deliberation processes, on process structures, and implementation commitments, is shaped by the existing power relations. Different stakeholders, owing to individual behaviors, institutional orientations, and organizational priorities, might be rigid and tend to compel others in making consent (O'Leary 2014). On the other extreme, power might also be defined as voluntarily entering into collective interest. This depends on the fact that governance concerns become well defined, involved all actors in the whole process, and incorporated the influence of many stakeholders (O'Flynn and Wanna 2008). Therefore, Harrington (2017) counsels that the dynamics of power relations should be safely guarded; otherwise, it will bring insecurity, instability, another layer of burden on water, voluntary breaching of rules, and contradicting approaches. This, ontologically, 
requires understanding and respecting the cultural, organizational, ecological, economic, social, and political context in which water governance is affected (Table 1).

Since the scientific process of exploring collaboration among various stakeholders is dynamic and complex, the transdisciplinary theoretical approach addresses the weakness of relying on one or two theories. Accordingly, the theoretical approaches of diverse scholars are combined to explore the collaboration of stakeholders from different dimensions. As the theoretical approaches inform about the nature of collaboration, organizing principles, aggregation of action plans, and sustainability strategies, a combination of such approaches is applied in this study.

\section{Analytical frameworks}

Analyzing a collaborative governance phenomenon that captures the energy, anticipation, threat, interest, and character of a diversity of stakeholders is daunting. Thus, sketching a model of analysis drawn not just from the empirical evidence but also from the complexity of backgrounds is critical to control an existing context and unanticipated dynamics. Henceforth, this enables one to address the question of the effectiveness of outcomes and sustainability. Ansell and Gash (2007), known in their theory of collaborative governance, introduced that a formal and inter-organizational process of collaboration is important, for it is owned by the public bodies that are more public-spirited. However, they neglected the interest, expectation, and priority of other stakeholders that potentially affect governance activities. More extensively, Emerson et al. (2011) synthesized an appreciable dozen of studies, empirical evidence, and theories that emerged across a range of governance contexts and developed an integrative governance framework deemed applicable to this study. Principled engagement, shared motivation, and capacity for action strongly influence the conjunction of prioritization and structure of collaboration among various stakeholders (Emerson et al. 2011). The symmetry that stems from this is that stakeholders can have iterative, interactive, and context-sensitive collaborative governance. Trust, legitimacy, commitment, discovery, determination, rearrangements, knowledge, and resources would be combined to bring effective actions, maximized output, and adaptability of frameworks (Emerson et al. 2011). The other important factor that influences the interaction of power and structure of collaboration is related to drivers of engagement (Alfredo et al. (2016). Drivers involve the leadership quality, institutional priorities, and prior history of collaborations (Ansell and Gash 2007; Eppel 2014).

Table 1 Theoretical frameworks used in this study. Source: Adapted from Ansell and Gash (2007), Emerson et al. (2011) and Bryson et al. (2015)

\begin{tabular}{|c|c|c|}
\hline Elements of collaborative governance activity & Defining characteristics & Sources \\
\hline Two-way communication & $\begin{array}{l}\text { Exchanging/giving and taking feedbacks, infor- } \\
\text { mation, developing the way forward }\end{array}$ & $\begin{array}{l}\text { Ansell and Gash (2007), Emerson et al. (2011) } \\
\text { and Bryson et al. (2015) }\end{array}$ \\
\hline Face-to-face deliberation process & $\begin{array}{l}\text { Discussion, incorporation of the ideas of all } \\
\text { participant actors, active participation of all } \\
\text { actors }\end{array}$ & $\begin{array}{l}\text { Ansell and Gash (2007), Emerson et al. (2011) } \\
\text { and Bryson et al. (2015) }\end{array}$ \\
\hline Prehistory of collaboration & $\begin{array}{l}\text { Experience of working together on common } \\
\text { issues }\end{array}$ & $\begin{array}{l}\text { Ansell and Gash (2007), Emerson et al. (2011) } \\
\text { and Bryson et al. (2015) }\end{array}$ \\
\hline Institutional design & $\begin{array}{l}\text { Openness and transparent nature of collabora- } \\
\text { tive governance, involvement of different } \\
\text { sectors }\end{array}$ & $\begin{array}{l}\text { Ansell and Gash (2007), Emerson et al. (2011) } \\
\text { and Bryson et al. (2015) }\end{array}$ \\
\hline Trust building & $\begin{array}{l}\text { Achieved through working in different levels of } \\
\text { collaborative governance activities for a long } \\
\text { period of time }\end{array}$ & $\begin{array}{l}\text { Ansell and Gash (2007), Emerson et al. (2011) } \\
\text { and Bryson et al. (2015) }\end{array}$ \\
\hline Commitment & $\begin{array}{l}\text { Sense of ownership, responsibility, taking part } \\
\text { in the implementation activities }\end{array}$ & $\begin{array}{l}\text { Ansell and Gash (2007), Emerson et al. (2011) } \\
\text { and Bryson et al. (2015) }\end{array}$ \\
\hline Shared understanding & $\begin{array}{l}\text { Having common objective, strong mutual } \\
\text { learning process }\end{array}$ & $\begin{array}{l}\text { Ansell and Gash (2007), Emerson et al. (2011) } \\
\text { and Bryson et al. (2015) }\end{array}$ \\
\hline Legitimacy & $\begin{array}{l}\text { Acceptability of collaborative governance by } \\
\text { the collaborating sectors and by the non- } \\
\text { collaborating sectors }\end{array}$ & Emerson et al. (2011), Bryson et al. (2015) \\
\hline Actions, sustainability, and adaptation & $\begin{array}{l}\text { Joint implementation, monitoring, evalua- } \\
\text { tion, risk taking, just distribution of utilities, } \\
\text { addressing unexpected risks, guarantee- } \\
\text { ing more diverse structures, and ensuring } \\
\text { dynamic collaboration }\end{array}$ & Emerson et al. (2011) \\
\hline
\end{tabular}


Another analytical model to learn is that of Alfredo et al. (2016) Thoughtful consideration and management of the initial inclusion of various stakeholders determine the changing approach of interaction among stakeholders. Agranoff (2006) noted that a competitive process of engagement in the process of governance to maximize one's private utility perils the advancement of collaborative governance as new stakeholders and processes suffer from risks and fragmented potentials (Agranoff 2006). To address such concerns, a three-tiered activity that involves securing consensus, rearranging focus on successful experiences, and avoiding artificial deadlines is helpful (Schneider et al. 2015). However, rather than avoiding poorly performing actors, Schneider et al. (2015) noted that a rearranged and continued dialogue along with encouragement and inclusion processes builds the power, improves the structure of collaboration, and maps the prioritization of issues among stakeholders.

Reviewing a set of studies ranging from law to politics, sociology to indigenous people's self-determination, Megdal and Eden (2017) explained that context is highly important in which the interplay of drivers, structures, and priorities is dependent. Contexts particularly refer to cultural, political, social, settlement, and economic settings. Thus, context is used as a means to integrate the structure, process, and priorities and to understand collaborative governance practices in various urban water projects. In this study, the analytical tools of the aforementioned themes are applied to analyze the structure and process of collaboration among diverse stakeholders. The reason is that a rich finding that reflects upon the fundamental nature of collaboration could be extracted through the mixed use of various concepts.

\section{Materials and methods}

\section{Study area}

This study is geographically delimited at Addis Ababa City water resources. Addis Ababa water bodies are facing a variety of problems that are represented by industrial pollutions and solid wastes from households and institutions and organizations (Figs. 1, 2).

Addis Ababa water bodies are characterized by a variety of characteristics. The following statement quoted from Leta et al. (2016) provides a notable description of the main elements of Addis Ababa water bodies (Table 2).

The textural composition of the soils in the different locations of the catchments suggests that the Eutric Vertisols are clayey in texture, which is an indication that the water infiltration capacity is poor. On the other hand, Cambisols in the upper catchments are sandy in texture, which is essential for a good infiltration and subsequent recharge of the aquifers in the lower catchments of the watershed, although this depends on good cover of the soil surface with perennial vegetation. Alternatively, this area should not be used for cultivation since it is a critical recharge spot for the downstream aquifers (Leta et al. 2016).

The common formations of Addis Ababa water bodies are the quaternary scoria, scoriaceous and vesicular basalts, Pliocene-quaternary fine-grained ignimbrites, tufts and rhyolite, middle Miocene basalts, and Oligocene rhyolites (Leta et al. 2016). The sub-watershed hydrogeology is formed by productive aquifers, moderately productive aquifers and minor aquifers in the middle parts, and poorly productive aquifers at the top of Entoto and highly productive aquifers at the southern end toward the outlet of the sub-watershed. The aquifers are unconfined (largely in the southern parts), confined and semi-confined (in the middle and uppermost parts) at different positions of the sub-watershed. Many of the cold and hot springs are found in the upper and middle catchments in this sub-watershed. Thermal deep well boreholes in confined aquifers are found in the middle catchments (e.g., at the Filwoha Hotel, National Palace, Hilton and Ghion Hotels), and cold water deep boreholes yield from 3 to $8 \mathrm{l} / \mathrm{s}$ in several locations in middle and lower catchments (Environmental Protection Authority of Addis Ababa City 2017).

\section{Data sources and collection tools}

The materials necessary for the collection of statistical and empirical data were sourced from the quarterly and annual reports of AARRCCAPO, the discussion reports of Water Management Boards, and other documents. These data were combined with the data collected through interviews and focus group discussions held with various experts, focal persons, and directors. The interview was conducted with different individuals that have knowledge and experience about water project sites. Besides, individuals that have an active engagement in the deliberation processes were interviewed. These interviewees include river project directors, river experts, mobilization committee members, members of river boards, focal persons, evaluation committees, directors of various stakeholders, members of various community organization committees, and other individuals that have a relation with water governance programs. Based on the principle of data saturation (Bogdan and Biklen 1998), which represents a point at which data collected from the interviewees become redundant, a total of 53 individuals were interviewed. The interviewees were selected with the help of purposive and snowball sampling which guided to make a criteria-based and informed selection of interviewees. The criteria were organizational responsibility, expert 


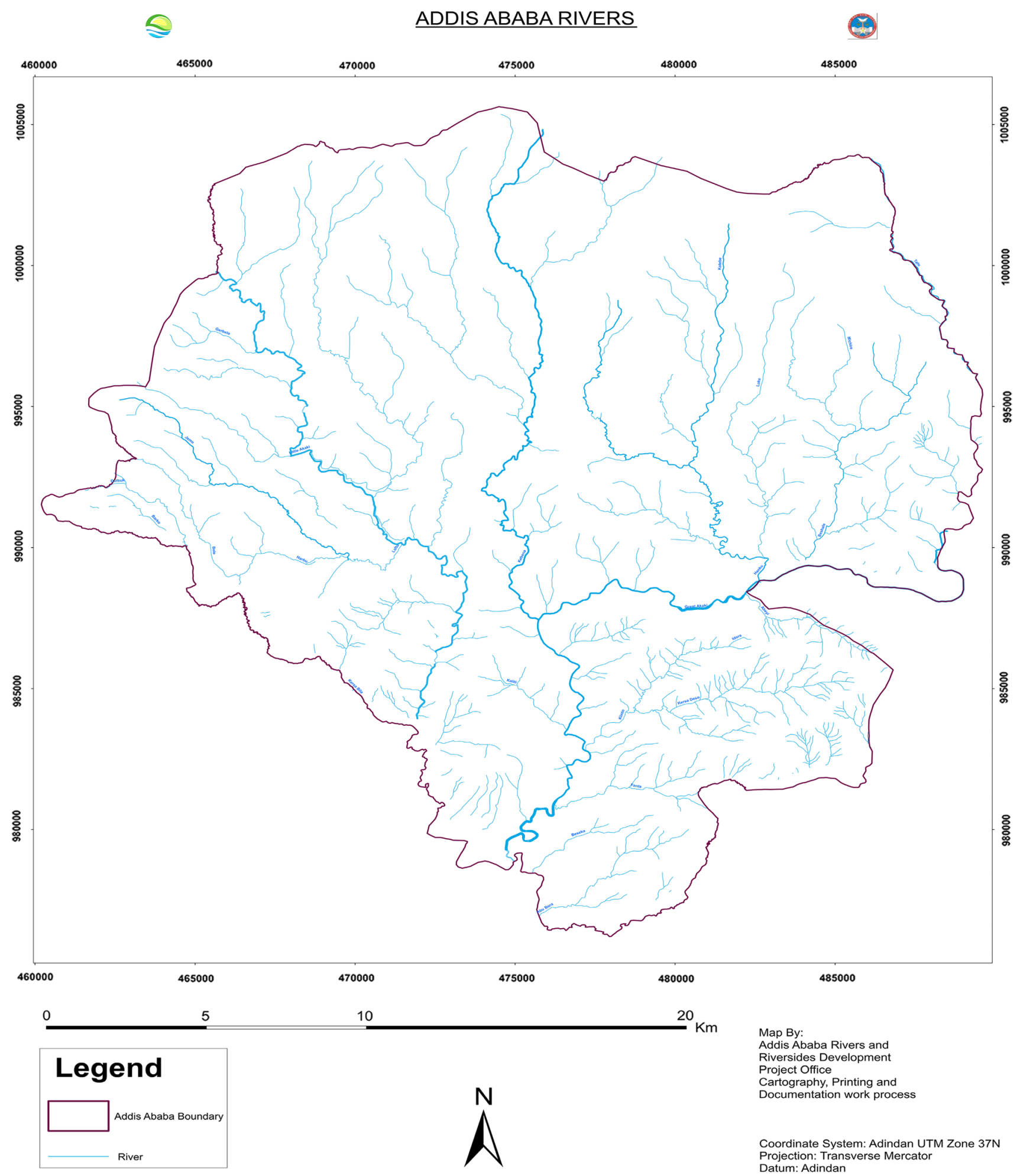

Fig. 1 Map of Addis Ababa water bodies. Source: Addis Ababa Rivers Riversides Climate Change Adaptation Project Office (2017a, b)

knowledge, and experience of water governance. The list of interview participants is presented in Table 3.

Focus group discussion (FGD) was also conducted with three groups of individuals. The first one was with various directors and board members. This is because they have deep knowledge about the process of deliberation and the governance of various river project sites. Second, the focus group was also conducted with representatives of various 
Fig. 2 Monthly flow of rivers across the various watersheds in Addis Ababa City. Source: Leta et al. (2016)

Table 2 Area in hectare size of land cover and land cover changes of Addis Ababa water bodies. Source: Leta et al. (2016)

\section{Monthly River Flow rates of the major watershed (MCM)}

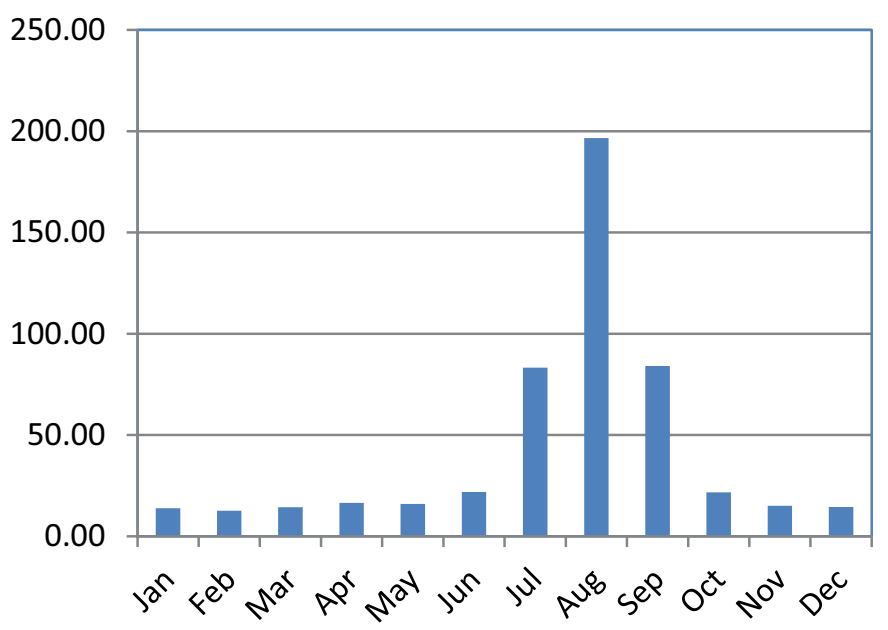

Flow rate $(\mathrm{MCM})$

\begin{tabular}{|c|c|c|c|c|c|c|}
\hline \multirow[t]{2}{*}{ Land-use classes } & \multicolumn{2}{|l|}{1985} & \multicolumn{2}{|l|}{1995} & \multicolumn{2}{|l|}{2015} \\
\hline & Area in (ha) & Area in $(\%)$ & Area in (ha) & Area in $(\%)$ & Area in (ha) & Area in $(\%)$ \\
\hline Built-up & $12,373.56$ & 8.38 & 9757.08 & 6.61 & $23,016.0$ & 15.60 \\
\hline Forest & $19,079.73$ & 12.93 & $18,158.49$ & 12.30 & $22,984.0$ & 15.57 \\
\hline Water body & 857.97 & 0.58 & 406.53 & 0.27 & 416.4 & 0.28 \\
\hline Agriculture Grassland & $115,226.28$ & 78.09 & $119,215.44$ & 80.80 & $101,121.1$ & 68.53 \\
\hline Total & $147,537.5$ & 100 & $147,537.5$ & 100.0 & $147,537.5$ & 100.0 \\
\hline
\end{tabular}

Table 3 List of interviewees and their affiliation. Source: Developed by the author

\begin{tabular}{|c|c|c|c|}
\hline No. & Interviewees' affiliation & Date of interview & Remark \\
\hline 1 & Addis Ababa Environmental Protection Office & January 02,2018 & 3 officials \\
\hline 2 & Community-Based Organization from Addis Ketema, Yeka, Bole, and Lideta sub-districts & January 05, 2018 & 6 officials \\
\hline 3 & Community-Based Organization from Akaki Kaliti, Nifas Silk, and Gulele sub-districts & February 10, 2018 & 6 officials \\
\hline 4 & Community based organizarions from Kirkos sub-district & February 16, 2018 & 2 \\
\hline 5 & Heinrich Böll Stiftung - the Green Political Foundation & February 21, 2018 & 2 directors \\
\hline 6 & Self-Help non-governmental organization & March 02, 2018 & 1 expert \\
\hline 7 & Australian Embassy Development Cooperation & March 03, 2018 & 1 expert \\
\hline 8 & Environmental Specialist at WBG & March 03, 2018 & 1 expert \\
\hline 9 & Addis Ababa Rivers Riversides Climate Change Adaptation Project Office & March 06, 2018 & 5 experts \\
\hline 10 & Youth With A Mission Ethiopia & March 10, 2018 & 3 experts \\
\hline 11 & Sewoch Lesewoch Dirgit (non-governmental organization) & March 12, 2018 & 2 directors \\
\hline 12 & Addis Ababa Environmental Protection Authority & March 14, 2018 & 2 officials \\
\hline 13 & House Construction Bureau & March 16, 2018 & 2 officials \\
\hline 14 & Land Management and Registration Bureau & March 18, 2018 & 2 officials \\
\hline 15 & Economic and Social Affairs of the United Nations & March 19, 2018 & 1 director \\
\hline 16 & 4 Anonymous representatives of 3 hotels & March 21, 2018 & 4 \\
\hline 17 & 5 Anonymous representatives of Garage operations & March 21, 2018 & 5 \\
\hline 18 & Trade Bureau & March 23, 2018 & 3 \\
\hline 19 & Industrial Bureau & March 25, 2018 & 2 \\
\hline
\end{tabular}


Table 4 Focus Group Discussion participants and their affiliation (FGD 1). Source: Developed by the author

\begin{tabular}{llll}
\hline No. & Focus group participant's affiliation & Date of FGD & Remark \\
\hline 1 & Environmental Protection Authority & May 10, 2018 & 1 official \\
2 & AARRCCAPO & May 10, 2018 & 1 official \\
3 & Addis Ababa University & May 10, 2018 & 1 official \\
4 & Industrial Impact Assessment Organization & May 10, 2018 & 1 official \\
5 & Organization of Community-Based Organizations & May 10, 2018 & 1 official \\
\hline
\end{tabular}

Table 5 Focus Group Discussion participants and their affiliation (FGD 2). Source: Developed by the author

\begin{tabular}{llll}
\hline $\begin{array}{l}\text { No. } \\
\text { Focus group participant's affili- } \\
\text { ation }\end{array}$ & Date of FGD & Remark \\
\hline 1 & Anonymous hotel & May 15, 2018 & 1 director \\
2 & Anonymous business enterprise & May 15, 2018 & 1 director \\
3 & Garage owner & May 15, 2018 & 1 focal person \\
4 & House Construction Bureau & May 15, 2018 & 1 expert \\
5 & Heal Management Bureau & May 15, 2018 & 1 expert \\
\hline
\end{tabular}

stakeholders in various deliberation forums. Third, FGD was also held with focal persons who are appointed to make regular supervision and evaluation of river sites. These individuals provided important information about the level of collaboration among various stakeholders in the implementation of action plans. Based on purposive sampling technique, focus group participants were selected based on their engagement and expert knowledge in the process of water governance. In each focus group discussion, six discussants participated. A complete list of the profile of the FGD participants is demonstrated in Tables 4, 5, and 6.

\section{Document review}

Different documents that were collected from the AARRCC APO were reviewed to get relevant data for the study. These secondary sources are unpublished reports, journals, and articles. Secondary sources provided an in-depth explanation and information about the problem being investigated from different perspectives. Secondary data were collected from quarterly performance assessment reports, annual performance assessment reports, river management board discussion reports, discussion forum/workshop presentation papers, and different researches that were conducted on Addis Ababa Water Projects. All these secondary data were collected through archiving the Web sites of Environmental Protection Authority of Addis Ababa City, AARRCCAPO, and other Internet sources. Besides, the unpublished research works and quarterly and annual reports were also collected through the investigation of the database of AARRCCAPO with the guidance of the external relations communications directorate office, and through communication directly with the Riversides Team Officer and deputy directors of AAR RCCAPO (Figs. 3, 4, 5, 6, 7, 8, 9).

\section{Method of analysis}

The data collected were analyzed thematically. As the major focus is analyzing the collaboration of different stakeholders in the governance of water bodies in Addis Ababa, the experiences and reflections of the study participants were categorized under different themes. The process of collaboration among different stakeholders has a complex phenomenon which requires searching for the common explanations stressed by the data collection participants and categorizing them under different themes. Based on the recommendations of Braun and Clarke (2006), specific emphasis was given to how the study participants explain the process of collaborations, by associating and categorizing them under the theoretical frameworks developed in the study. In this way, the findings of the study are explained comparatively to other related study findings.
Table 6 Focus Group Discussion participants and their affiliation (FGD 3). Source: Developed by the author

\begin{tabular}{llll}
\hline No. & Focus group participant's affiliation & Date of FGD & Remark \\
\hline 1 & Non-governmental organization & May 20, 2018 & 1 focal person \\
2 & Focal person from Gulele sub-district & May 20, 2018 & 1 focal person \\
3 & Focal person from Akaki Kaliti sub-district & May 20, 2018 & 1 focal person \\
4 & Industrial Lid group & May 20, 2018 & 1 focal person \\
5 & Focal person from Yeka sub-district & May 20, 2018 & 1 focal person \\
\hline
\end{tabular}


Fig. 3 Theoretical framework of the study. Source: Developed by the author on the basis of review of studies

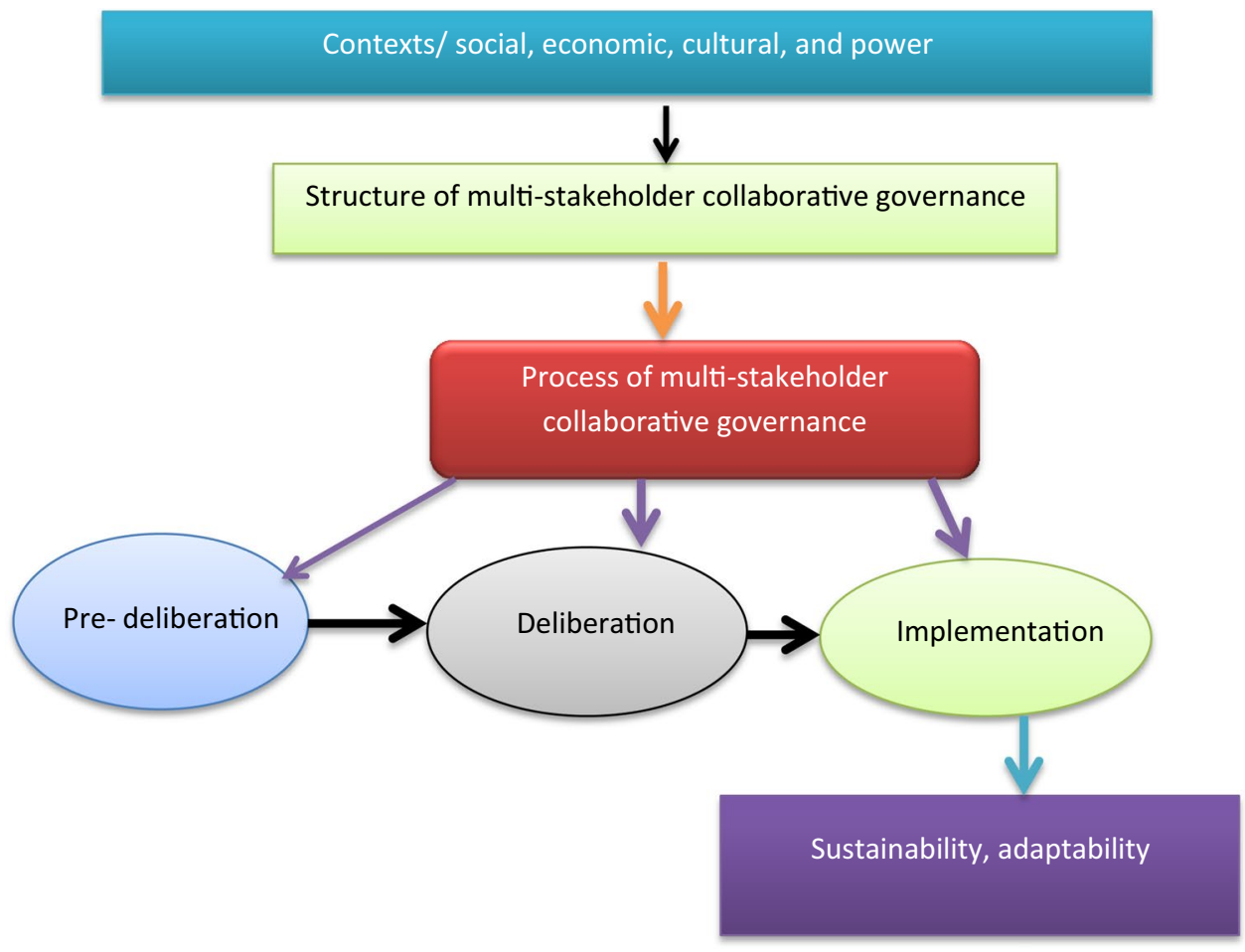

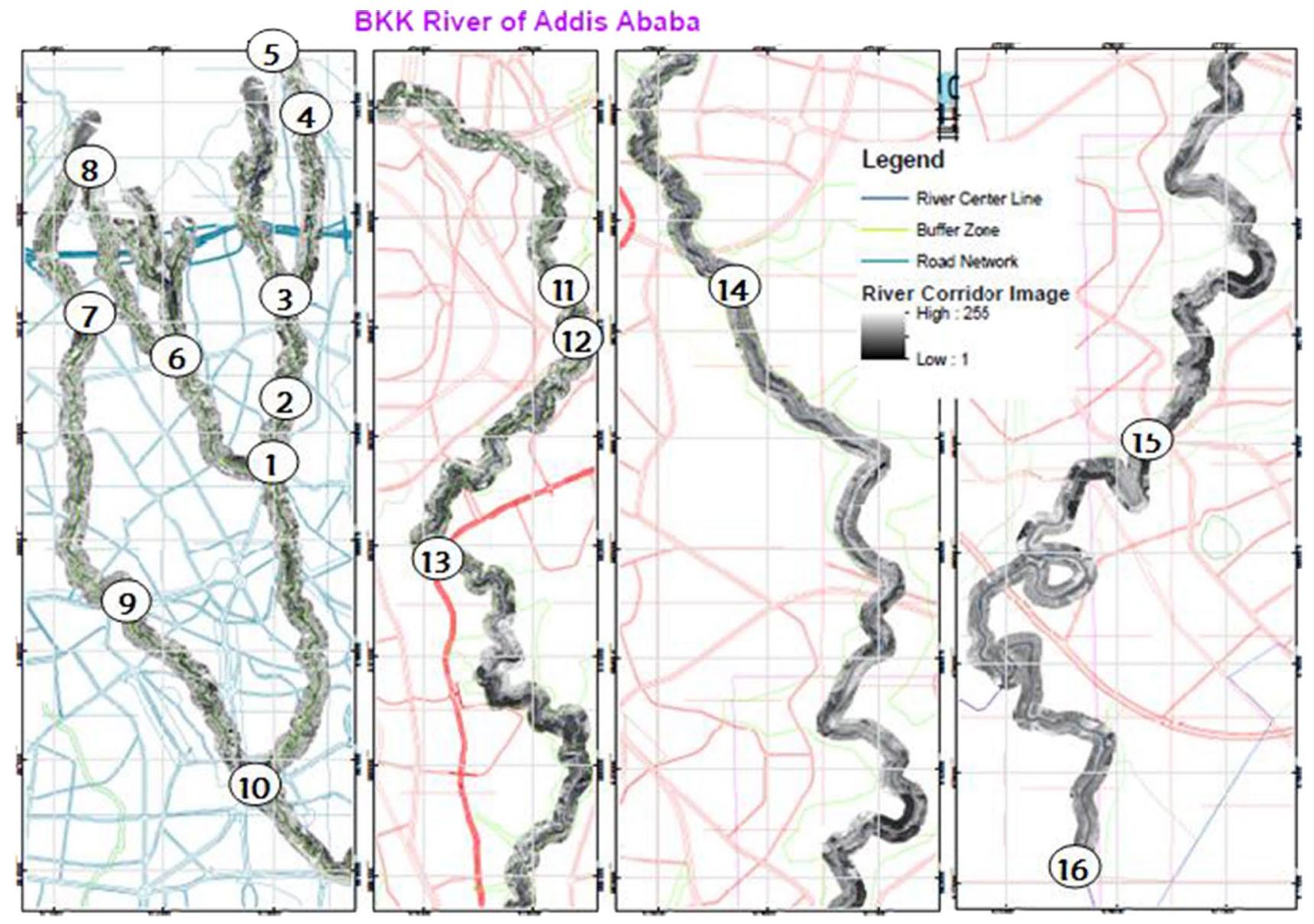

Fig. A GCP distribution of Addis Ababa Water Bodies. Source: Adapted from a Survey of Leta et al. (2016)

$\sqrt{ }$

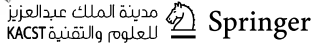




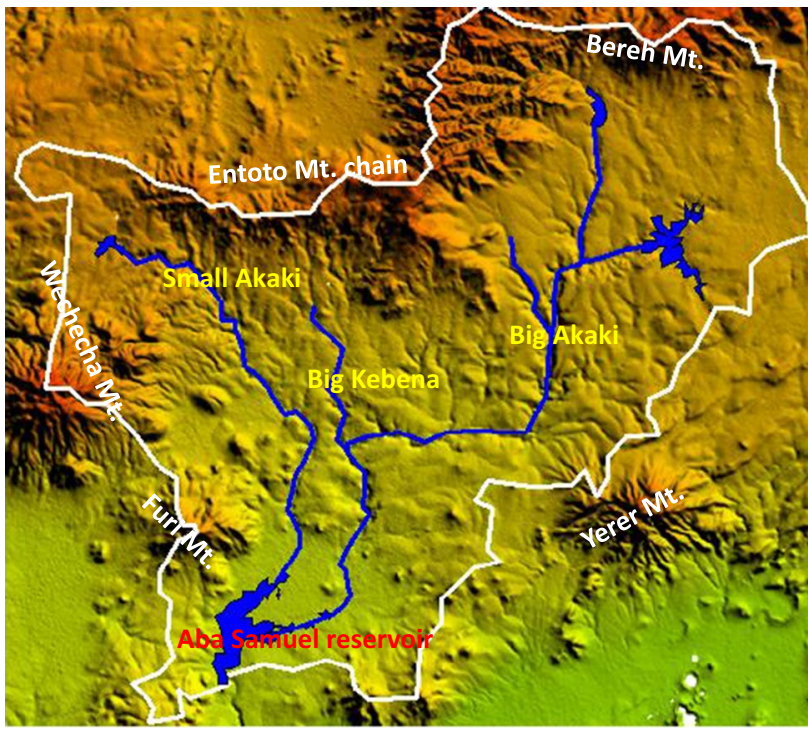

Fig. 5 A map that shows the DEM of the Aba-Samuel Reservoir Watershed showing the three major sub-watersheds formed by Small Akaki, Big Kebena, and Big Akaki rivers. Source: Adapted from the survey of Leta et al. (2016)

\section{Results of the study}

\section{Analyzing the process of multi-stakeholder governance}

\section{Pre-deliberation mobilization activities: prehistory of collaboration}

The pre-deliberation frameworks are, generally, characterized by a diverse set of procedures that create a differing level of appeal to different stakeholders to participate in discussion forums. First, formal and informal mobilization structures have been employed with a different scale of impact in bringing the engagement of stakeholders in the discussion forums. The following notes provide an account of the way stakeholders were mobilized into the discussion forums.

...I participated in many of the collaborative discussion platforms because I was formally instructed by my organization (participants from government sectors). I tend to cooperatively work together with different sectors because of our earlier friendship (participant from the Land Management Bureau).
Fig. 6 Relative location of the Addis Ababa City in the large watershed (shown in the central part with a pink shade) and the three major sub-watersheds of Small Akaki, Big Kebena, and Big Akaki draining to the outlet at Aba-Samuel reservoir in the south. Source: Leta et al. (2016)

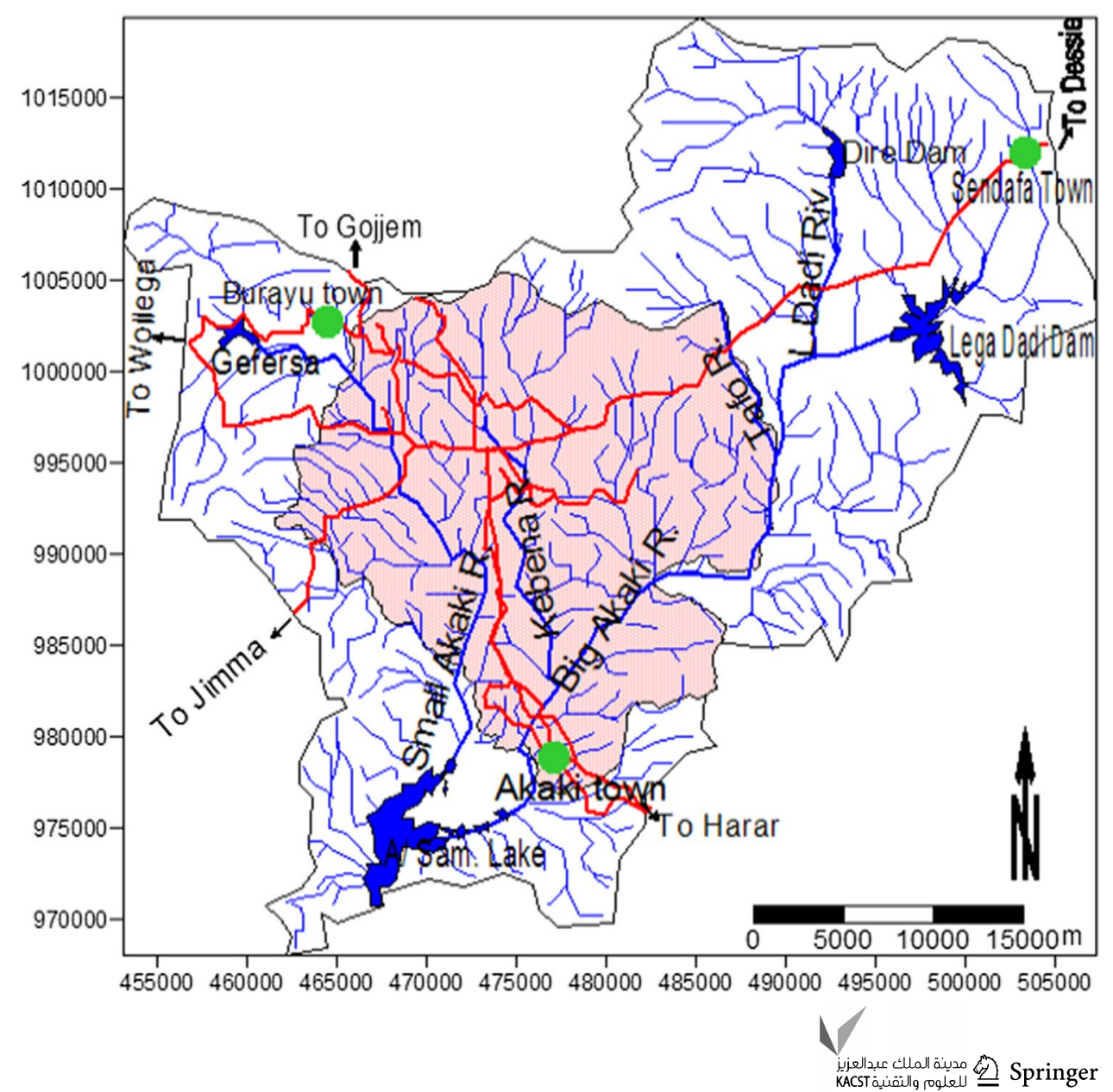



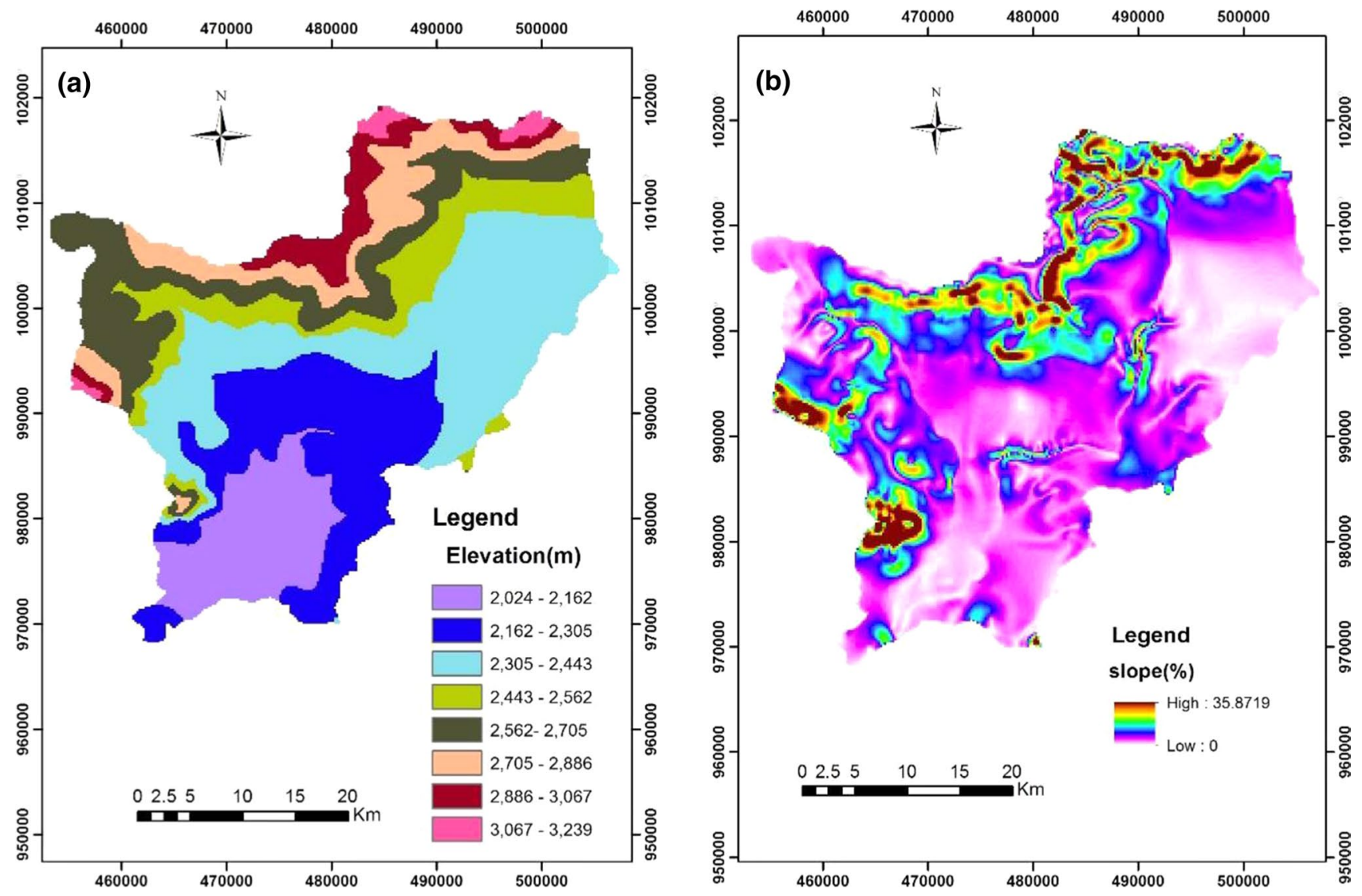

Fig. 7 Elevation and slope maps of the major/large watershed of the Aba-Samuel reservoir. Source: Leta et al. (2016)

Fig. 8 Recharge potential map of the catchments in the major/ large watershed of the Aba-

Samuel reservoir. Source: Leta et al. (2016)

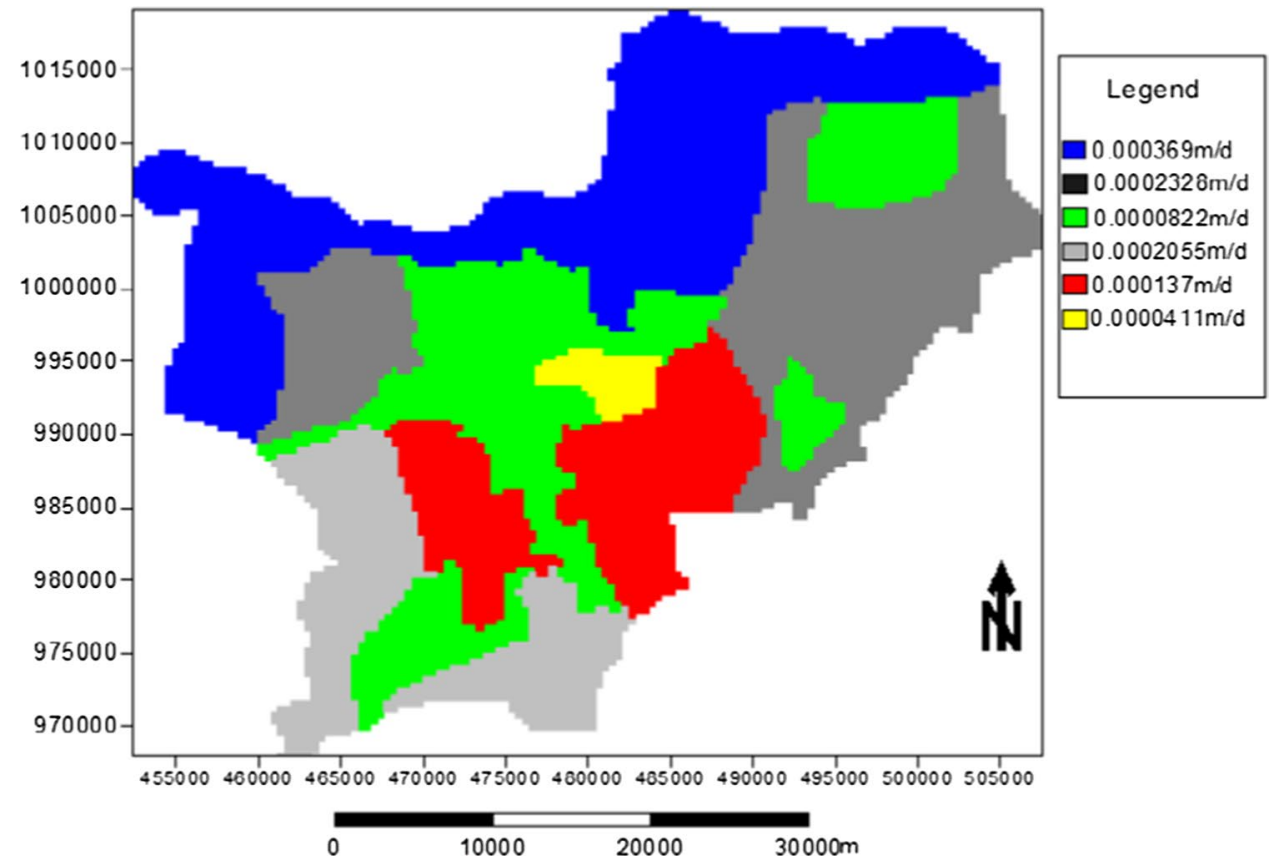



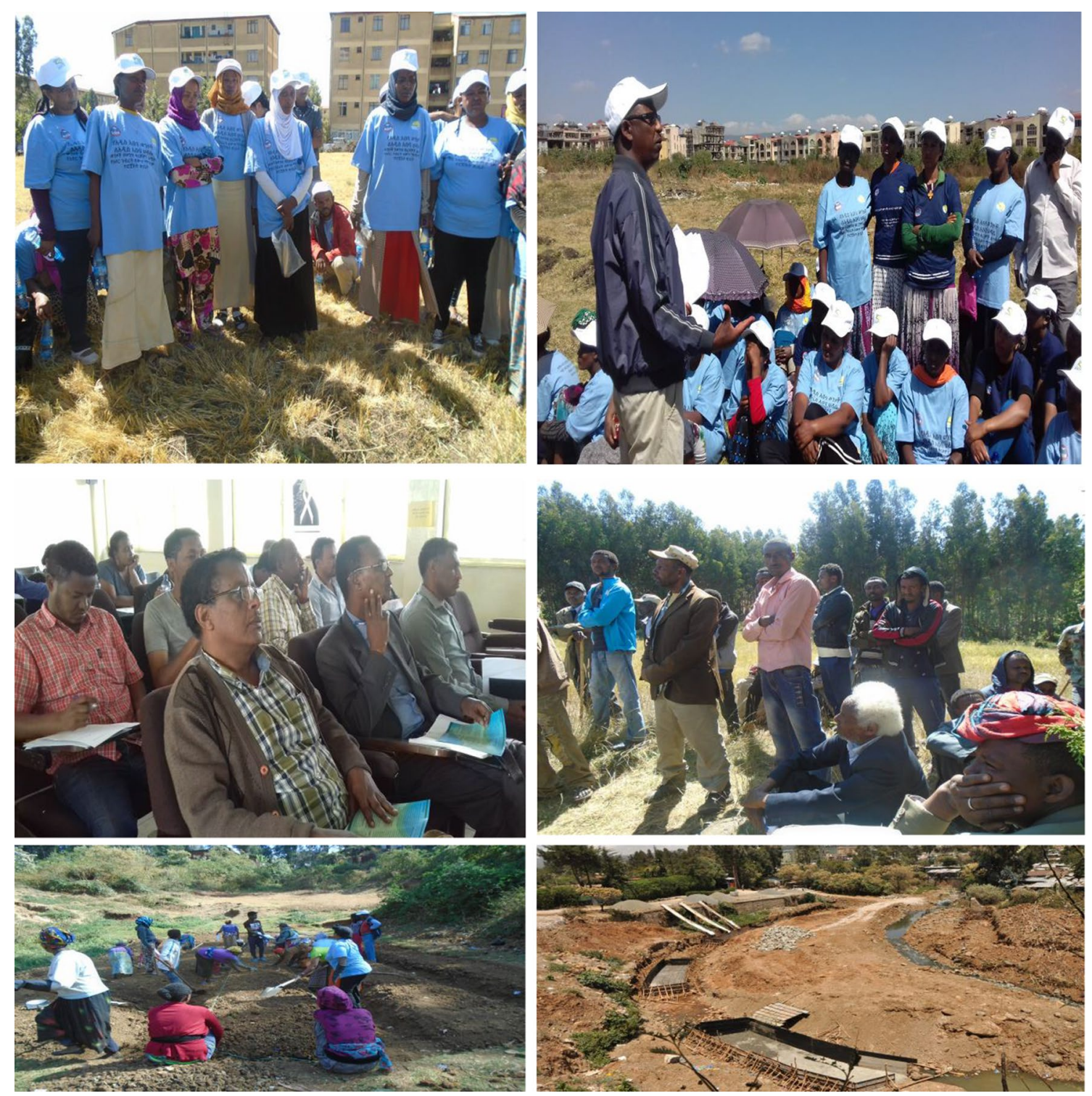

Fig. 9 Pictures that show the three phases of multi-stakeholder governance activities in various sites Source: Field visit, 2018-2019

Second, the organizers of the collaborative governance activities do not give equal consideration to all stakeholders though river governance requires consideration of a multiplicity of aspects of river problems: ecological, health, societal, educational, sanitation, settlement, urban beautification, and security issues. Therefore, potentially relevant stakeholders were not mobilized sufficiently enough to take part in the collaborative governance platforms, as the following quotations exemplify.

I was simply obliged to go to the collaborative discussion forums without having an orientation about the forums (participant from construction). The organizers did not give us their drafts; so I was simply watching during the discussion forums (trade Bureau).
Third, pre-deliberation collaborative structures are represented by the absence of clear and logical sequencing of events. Hence, stakeholders have been directed to provide information and data about rivers without being convinced and informed about the multi-stakeholder governance activities.

We are being asked to provide information without having mutual understanding and agreement on the issue (Land expert). Issues, which have to be dealt with in the later stages of the collaborative governance activity, are being raised by the project officers before even having a mutual interface (Beautification Expert). We are being asked to provide such information which requires an extended line of communication with other 
sectors. Besides, we strived to provide them with information with great commitment. Nonetheless, when we ask them further explanations on the inputs that we should provide them, they are not actively responding to us (Expert from House Construction Bureau).

Water governance activities are assumed to be the responsibility of all stakeholders. All stakeholders are expected to initiate collaborative structures to deal with river problems as river problems could not be addressed from a limited dimension. Nevertheless, the task of mobilizing and organizing various stakeholders into the collaborative platform to deal with Addis Ababa Water Projects is assumed to be the responsibility of few stakeholders alone while other stakeholders keep unconcerned unless they are driven or pushed.

...it is the responsibility of other sectors because we have our agenda to deal with (interviewee from five sub-cities and stakeholders).

Mobilization activities are carried out without due regard to all stakeholders, based on the basic organizers' assumption that excludes potential stakeholders. The fundamental paradigm (urban water is the concern of few sectors) held by organizers is creating negligence and low regard for the role of all stakeholders to participate in the governance of water problems in Addis Ababa. The following quotations taken from the interviewees and focus group participants provide a representative example.

The fact that preexisting cross-sectoral networks are nonexistent, multi-stakeholder collaborations may not be compatible with NGOs (organizer of collaborations). Regarding collaboratively working with other stakeholders to govern rivers, no form of contact to establish interface has been formulated with us (Youth Association Participant). Though we have not been contacted to participate in the multi-stakeholder governance frameworks, we are trying to make practical initiatives to work on water governance tasks along with other sectors (participants from two NGOs).

This is also confirmed by the water assessment report made by Meklit et al. (2017) that the mobilization and organization of all the relevant stakeholders are threatened by the skills and knowledge of organizers. In the discussion forum of Water Management Boards, the directors agreed that since the techniques and procedures of mobilization are exclusive and ignorant of various stakeholders, a new approach has to be implemented (AARRCCAPO 2017a, b).

\section{Discussion forum structures and processes}

Multi-stakeholder dialogues, in most cases, are engulfed with few experts, while the majorities appear to be non-experts. As a result, the discussion forums are typically non-democratic, combining the ideas, comments, and advises of few participants. While non-governmental stakeholders lack the required expertise on the agenda and lack the previous history of collaborations, others are not interested in on account of economic principles. This could be understood from the following quotations.

...the meetings, except accommodations, are not constituted by financial accommodations which make the participants less appealed to come (River expert). Woreda (sub-district) level authorities are not interested in coming to the negotiation table as they have no strong awareness of water concerns (Environmentalist).

We have recognized the importance of having a common understanding forum in which idea-sharing, knowledge building, and mutual relationships could be strengthened. However, we are not effectively working on that as the regular interfaces are limited (River Governance Director).

The other conventional manifestation of multi-stakeholder collaborative processes is the lack of a two-way exchange of information, documents, and drafts to come into common terms for the collaborative tasks, as the following quotations exemplify.

We sent various documents and the sectors are irresponsible and not committed to sending back the documents with their suggestions (River Expert). Even trying to reach them is a challenging problem (Environmentalist). We are of course provided with the agendas and preliminary works to be well digested in the consultation forum. Even so, we do not have an exchange of ideas before the deliberation program is conducted (participants from Trade, Beautification, and Sanitation Bureaus).

Though multi-stakeholder collaborative governance structures are highly influenced by the availability of various mobilizing committees, the existing steering committees are minimal and lack the involvement of different stakeholders. As demonstrated in Table 7, responsible stakeholders were neglected in critical governance processes. Though there exist plenty of other relevant stakeholders, few of them are taking part. The following table explains the number of steering committees and the participant stakeholders.

In the quarterly report of AARRCCAPO (2017a, b), it is recognized that the involvement of various stakeholders from society, government, civil society, international organizations, and business groups is absent. Besides, the annual reports also made a similar statement that multistakeholder discussion forums had been asymmetrically 
Table 7 Steering committees and constituting stakeholders. Source: Addis Ababa Rivers, Riversides Climate Change Adaptation Project Office (2017a, b)

\begin{tabular}{lll}
\hline No. $\quad$ Name of steering committee & Member stakeholders \\
\hline 1 & Addis Ababa-Oromiya Integrated River Project & Public Organization (Addis Ababa Rivers \\
& Riversides Project Office, Addis Ababa Water \\
& Sewerage Authority, Addis Ababa Environ- \\
& mental Protection Authority, Oromiya Forest \\
& and Climate Change Office, Oromiya Water \\
& and Energy Bureau, and Oromiya House and \\
& City Development Bureau). No members \\
& from CBOs, NGOs, Civil Societies, Business \\
& Groups \\
Addis Ababa Rivers and Riversides Project Office & Public Organizations (Ababa Rivers Riversides \\
Management Board & Project Office, Addis Ababa Water Sewerage \\
& Authority, Environmental Protection Author- \\
& ity, Addis Ababa Municipality, Education \\
& Bureau, Addis Ababa Administration, House \\
& Construction Bureau, Land Administration \\
& Bureau, Planning Bureau); no participants \\
& from CBOs, NGOs, Business Groups, Civil \\
& Societies
\end{tabular}

structured against the involvement of various non-governmental stakeholders.

\section{Outcomes of multi-stakeholder collaborative governance processes}

\section{The unbalanced distribution of power}

Power is among the significant elements of collaborative water governance schemes (Marie and Rob 2016), for it fuels different stakeholders with responsibility, query, initiative, and energy to engage in the governance of water problems. There exist divergent levels of engagement of different stakeholders with different levels of participation, sharing of common concerns, and pressing on water issues. This phenomenon is an outgrowth of the processes and structures of collaboration among various stakeholders, with the existence of inclusion and exclusion, early involvement and late involvement, creating asymmetrical power among stakeholders. The following statistical data collected from the AAR RCCAPO reveal this fact (Table 8).

Table 8 provides evidence that collaborative governance, though desired and imitated by the public organization, suffers from the limited participation of stakeholders. As a result, major decisions are reflective of a few stakeholders' interest and priority. This structured the power relationship in a fragmented manner, thereby making the majority of non-state actors unable to press their influence and shape the water governance programs. This stands contrary to what Emerson et al. (2011) and Ansell and Gash (2007) suggested that there must be a balanced approach of integrating various stakeholders in the collaborative governance to excel dynamism and maturity of programs.

\section{Ineffective implementation of water governance action plans: commitment, institutional building}

This is the stage in which the participation of various stakeholders in the collaborative governance activities is required. The mini-level involvement of stakeholders in the pre-deliberation process of collaborative governance tasks leads to the existence of ineffective implementation of action plans. The absence of preliminary communication systems and consultation forums resulted in the absence of co-ownership and co-responsibility to collectively follow up and supervise the implementation of action plans (Table 9).

The table demonstrated that institutional setting and commitment of the stakeholders are constraining the effective exchange of resources to facilitate collective governance.

\section{The existence of conflict among various stakeholders: limited legitimacy and mutual understanding}

The existence of conflicts against the community is another event that shows how the stakeholders are working ineffectively with the community in governing water problems in Addis Ababa. This shows that the structure and procedure of collaboration among various stakeholders are not well designed in accordance with the institutional settings and policy environments as could be understood from Table 10. Moreover, the method of facilitating the collaboration of stakeholders is facing a challenge as it failed to be addressed and determined in the pre-deliberation stages.

Therefore, the lack of early engagement of various stakeholders in the collaborative governance platforms is fueling later-stage communication and collaboration procedures. The structure and procedure of collaborative governance neglected the cultural and economic context of stakeholders. 
Table 8 Participation of stakeholders in various water governance deliberation forums. Source: Addis Ababa Rivers Riversides Climate Change Adaptation Project Office (2017a, b)

\begin{tabular}{|c|c|c|c|c|c|c|c|}
\hline \multirow[t]{2}{*}{ No. } & \multirow{2}{*}{$\begin{array}{l}\text { Discussion forums on urban water } \\
\text { governance }\end{array}$} & \multicolumn{5}{|l|}{ Participating stakeholders } & \multirow[t]{2}{*}{ Remarks } \\
\hline & & Public organizations & Private organizations & NGOs & Universities & CBOs & \\
\hline 1 & $\begin{array}{l}100 \mathrm{~km} 100 \text { m River Rally Discussion } \\
\text { Forum at Ambassador Hotel }\end{array}$ & 20 government organizations & 2 hotels & 0 & $\begin{array}{l}1 \text { (Addis } \\
\text { Ababa Uni- } \\
\text { versity) }\end{array}$ & 2 & \\
\hline 2 & $\begin{array}{l}100 \mathrm{~km} 100 \text { m River Rally Discussion } \\
\text { forum at Panorama Kazanchis Hotel }\end{array}$ & 17 government organizations & 2 agricultural researchers & 0 & 0 & 4 & \\
\hline 3 & $\begin{array}{l}\text { Discussion forum on Addis Ababa } \\
\text { Rivers at Gihon Hotel }\end{array}$ & 18 & 0 & & 1 & 0 & \\
\hline 4 & $\begin{array}{l}\text { Discussion forum on Addis Ababa } \\
\text { Rivers at Panorama Hotel }\end{array}$ & 32 & 0 & 0 & 0 & 0 & \\
\hline 5 & $\begin{array}{l}\text { Discussion forum on Addis Ababa } \\
\text { Rivers at Ambassador Hotel }\end{array}$ & 7 & 1 independent researcher & 0 & 0 & 0 & \\
\hline 6 & $\begin{array}{l}\text { Discussion forum that was held at } \\
\text { Addis Ababa Rivers Riversides } \\
\text { Project Office }\end{array}$ & 30 & 0 & 0 & 0 & 5 & \\
\hline 7 & $\begin{array}{l}\text { Discussion forum that was held at } \\
\text { SheklaAfer River Site }\end{array}$ & 35 & 0 & 0 & 0 & 0 & \\
\hline 8 & $\begin{array}{l}\text { Discussion forum that was held at } \\
\text { Wengelawt Mariam }\end{array}$ & 34 & 2 & 1 & 1 & 1 & \\
\hline 9 & $\begin{array}{l}\text { Discussion forum that was held at } \\
\text { Ammanuel Condominium }\end{array}$ & 42 & 3 & 0 & 0 & 3 & \\
\hline 10 & $\begin{array}{l}\text { Discussion forum that was held at } \\
\text { Gelagle River Site }\end{array}$ & 37 & 1 & 2 & 4 & 0 & \\
\hline 11 & $\begin{array}{l}\text { Discussion forum that was held at } \\
\text { Jemmo River Site }\end{array}$ & 16 & 4 & 0 & 1 & 1 & \\
\hline 12 & $\begin{array}{l}\text { Discussion forum that was held at } \\
\text { Kebena River Site }\end{array}$ & 18 & 0 & 0 & 0 & 0 & \\
\hline
\end{tabular}

Three community-based organization members expressed their anger that they are relegated to the bottom of the hierarchy and their culture, economic interest, and settlement pattern are abused by the public officials (interviewees and focus group participants).

\section{Low level of participation in the evaluation of water governance projects: actions, adaptation, and sustainability}

The outcome of multi-stakeholder collaboration forums is expressed in evaluating water project sites. The employed women and youth unions who are tasked with the responsibilities of cleaning, protecting, and developing rivers have to be properly followed, and their activity has to be evaluated. Nevertheless, the collaboration of stakeholders is weak.

Even though the performance of the workers in implementing the required tasks in protecting and developing water has to be evaluated, it is not being done via collaborative frameworks. This is because there is no culture of regularly coming to the evaluation forums and meetings to evaluate and design better regulatory and effective action plans (River Director). There are sectors that give a deaf ear when the request is made to send focal persons for the evaluation of project sites as per the agreement signed in the discussion forums (Environmentalist). For the proper functioning of unions, schedules have to be developed to ensure that river cleanup, protection, and development activities are carried out in accordance with the action plans. However, the time tables are not developed by various responsible stakeholders (Environmental Protection Authority).

The quarterly reports elaborate that river project activities were not well evaluated on account of various factors. Even though various formal communications were made to take the feedbacks of various stakeholders in evaluating and developing further frameworks, few of the requested stakeholders provided recommendations (AARRCCAPO 2017a, b).

\section{Low level of participation in the supervision of river sites}

The level of participation of various stakeholders in the supervision of river sites is limited by the absence of focal 
Table 10 Conflicts that were experienced during the implementation of water project action plans. Source: Addis Ababa Rivers Riversides Climate Change Adaptation Project Office (2017a, b)

\begin{tabular}{lll}
\hline No. & Places of project sites & $\begin{array}{l}\text { Number of cases of con- } \\
\text { flicts with the community }\end{array}$ \\
\hline 1 & Kirkos sub-city, woreda 2 and 3 & 3 \\
2 & $\begin{array}{l}\text { Kazanchis sub-city woreda } 1,4, \\
\text { and 5 }\end{array}$ & 5 \\
3 & Arada sub-city woreda 7, 9, and 10 & 6 \\
4 & Lideta sub-city 3, 9,8 & 8
\end{tabular}

persons and regular schedules. The following quotes express this explicitly.

In many cases, the focal persons that are assigned in the regular supervision of river sites come from only governmental organizations (River Director). There are few focal persons that regularly check the supervision of river site activities (Focal person).

Similarly, annual and quarterly reports noted that there is inadequate participation of stakeholders in the regular supervision of river sites and the development of consistent action plans (AARRCCAPO 2017a, b).

\section{Ways of improving the collaborative process among stakeholders for effective governance of urban water projects: ensuring adaptation and sustainability}

Changing the context and driver of collaborations among stakeholders in governing urban water projects necessitates a rearrangement of the patterns of communications, inclusion of actors, determination of potential risks, and management of unexpected circumstances. Particularly, as Emerson et al. (2011) suggest, collaborative governance is built on a system context. Thus, it is worthwhile to build a legal, political, cultural, social, environmental, and economic landscape that democratizes pre-deliberation, deliberation, and implementation programs in Addis Ababa. Hence, the communities at sub-district, private actors, and government sectors have to participate in their capacity.

Since the process of engagement is not strong in Addis Ababa, a legal framework that situates urban water projects at the top of urban wise studies, discussions, consultations, and interests among various actors is important. This helps to shape the structure of collaboration in which all stakeholders regardless of power difference could act in governance frameworks according to their interests. Waste governance, land governance, ecosystem preservation, and infrastructure programs, and health governance issues have to be integrated with water governance activities. As Bryson et al. (2015) noted, this helps to compromise power

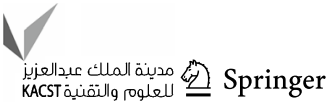


asymmetry, create a common platform, and rearrange contexts for the sake of water governance.

Drivers of action should be the primary agendas (Emerson et al. 2011). The existing experts and committees have to include stakeholders from both governmental and nongovernmental institutions. This helps to minimize unexpected risks, such as conflicts, disagreements, and lack of responsiveness in the implementation stages which are the main problems in Addis Ababa. Apart from this, the process of interaction could bring effective action if and only if the actors make consensus before rushing to the next steps (Ansell and Gash 2007). For this purpose, the social learning process has to be dealt with at various centers and contexts through which both local and country-level actors work jointly (Della Porta and Diani 2005). Finally, to ensure sustainability and adaptability, both provincial committees and permanent committees have to be arranged. The focal persons and committees that bridge the interaction of stakeholders in Addis Ababa have to be more democratic and effective through the following method. This involves the decentralization of committees across sub-districts, the appointment of committee members based on professional capacity, and the incorporation of other urban issues.

\section{Discussions}

The specific processes of collaboration among stakeholders in governing urban water projects are less studied in the context of Africa and Ethiopia. The study identified the problems that affected the democratic quality of collaborative water governance in Addis Ababa. Though there is the participation of stakeholders in the collaborative governance frameworks, it is dominated by government sectors. The participation of CBOs, NGOs, private organizations, though pivotal for more effective, holistic, and sustainable approaches of dealing with river concerns, is absent. Hence, the absence of diverse stakeholders resulted in the lack of hybrid composition of cross-administrative and institutional river cleanup, protection, and development systems, denying further opportunities for building institutional capacity for idea generation, trans-institutional learning, and sharing of responsibilities. This problem is related to the absence of a pre-deliberation history of collaboration. A study conducted in Brazil explained that the early incorporation of potential sectors and community-based organizations enables one to fill the existing lack of experiences of working together and thus to effectively address water issues (Abers 2007; Huxham et al. 2000). However, since there is no prehistory of collaborations among various sectors, the process of organizing and mobilizing stakeholders into the discussion forums requires long and complex bureaucratic procedures. However, Reynaud et al. (2015) noted that a flexible and simple process of establishing and developing multi-stakeholder dialogues and collaborations is essentially instrumental for effective water governance tasks.

Collaborative public management theory assures that since the facilitators have no power over other sectors, they have to depend on the styles and skills of facilitating, mobilizing, and activating stakeholders (Pahl-Wostl and Ross 2010). A study made by Arsano et al. (2010) to investigate water governance in Ethiopia noted the importance of improving the interaction of different stakeholders without specifying the specific procedures. Thus, this study demonstrated how a lack of pre-deliberation as an early procedure affects the democratic process of collaboration. Consequently, this has prevented the stakeholders from having a pre-deliberation assessment, consciousness, understanding, and knowledge of the agenda to actively and constructively contribute to the mutual learning process. Consequently, this brought a limited involvement of stakeholders in collaboratively supervising and evaluating project sites. This reflects poor prehistory of collaboration in affecting the commitment, institutional setting, and sharing of responsibilities.

Emerson et al. (2011) well noted that conducting thick face-to-face communications and breaking down stereotypes and disagreements are essential for an effective learning process. In the Ethiopian, Accra and South African context (Mutondo et al. 2016; Olagunju et al. 2019) studies show the advantage of incorporating diverse stakeholders' in the governance of water. Therefore, this study found out practical mechanisms of improving discussions and knowledge combining methods on water. Accordingly, the study shows that the existing discussion forums are not enough because the representation of sectors by professionals and experts as well influences the outcome of the deliberation processes. Initially, the representatives of participant sectors are not professionals in the area of environment, particularly river issues. As a consequence of this, the process of knowledge production failed to bring community consensus, thereby leading to the eruption of conflicts. Lack of context-sensitive process kills the sustainability and adaptation of projects.

The quality of deliberation is affected by the experience, expertise, and skillful advocacy of sectoral interests in the communication process (Emerson et al. 2011). Various stakeholders' authorities are not interested in coming to the negotiation table as they have no strong awareness of river concerns. Therefore, the study concludes that multistakeholder collaborations, in order to transcend from a simple process of having dialogues toward a quality level of knowledge sharing, proposal developments, and combinations of diverse perspectives (Hermansa et al. 2007), have to be entertained by the participation of individuals with good level of knowledge and experience about the governance of water problems. Individual's behavior also matters to govern water projects. 
The production of small wins, such as the incorporation of sectoral interests and pre-deliberation communications, deepens shared understanding which is an important avenue to create a widespread and multi-sectoral involvement in the implementation of action plans (Olsson and Head 2015). Particularly, lack of accountability, responsibility, and exclusion of groups are identified as factors that constrain the collaborative governance of water in Ethiopia, including other African urban centers (Olagunju et al. 2019; Arsano et al. 2010). Hence, this study helped to better understand the sources of lack of accountability, responsiveness, and fragmented engagements by stakeholders. The process of multistakeholder collaboration faces a multitude of setbacks: some sectors tend to exclude themselves because of the limited sense of ownership and awareness, and some stakeholders assign personnel, not experts, in such environmental concerns, and others oscillate between participation and nonparticipation with the change in leadership. Additionally, common understanding becomes difficult among the stakeholders, thereby making sectors indifferent to engage in the subsequent stages of the collaboration framework, such as the exchange of resources (Franzén et al. 2015).

The responsibility of mobilizing various sectors into the web of the collective task is in the hand of AARRCCAPO. Besides, the exchange of formal invitation letters between this facilitating sector and the other stakeholders is weak, for the authority and responsibility of the project office is not given due credit. Apart from facilitative styles emphasized by Abers (2007) as important to encourage the participation of stakeholders and exchange of information, this study found out that the acceptance or recognition of the letters of invitations from the organizers also affects the involvement of stakeholders. This helps to build legitimacy and trust.

The participation of stakeholders is not a guarantee for the aggregation of diverse viewpoints because active engagement necessitates integrating one's idea with the other, thoughtful examination of ideas, and rigorous methods of analyzing concepts to produce a common public agenda (Emerson et al. 2011; Megdal and Eden 2017; Pahl-Wostl et al. 2007). The contribution of this study is the identification of the capacity of water governance experts and institutional structures that affect the fruit of deliberations. The study identified that institutionalizing participatory water governance requires building the professional capacity of participant individuals that represent different sectors. Given that collaborative processes are naturally interactive and cyclical, lack of professional capacity among water governance experts affects performance in the later stages of the collaborative governance processes (Olagunju et al. 2019). Consequently, the adaptation of collective actions to the cultural and organizational context of stakeholders becomes difficult. Face-to-face dialogue breaks down stereotypes and communication discrepancies that prevent the exploration of mutually agreed points (Ansell and Gash 2007; Hermansa et al. 2007). The overall outcome is insufficient collaboration in the resource sharing, in supervision and evaluation activities, the combination of the interests of various stakeholders, and lack of professionals to sustainably deal with water problems.

To address the gaps and build an emerging trend, a critical and fresh focus on the drivers, actors, actions, and adaptations has to be made. Based on the discussions of Ansell and Gash (2007), Emerson et al. (2011), Bryson et al. (2015), and Della Porta and Diani (2005), the study identified the following critical areas of focus: establishing a multi-variant context system, strengthening both formal and informal structures, broadening the procedures of engagement and collaboration, establishment of various democratic forums, and closing the gap between plan and action through collective responsibility via provincial and permanent committees.

\section{Conclusion}

In this study, critical analysis of the process of multi-stakeholder collaborative governance processes and their impact on the collaborative governance of water problems in Addis Ababa City is made. It provided some specific procedures of democratizing, diversifying, and building the collaboration of stakeholders in governing urban water projects. The results show that the processes and structures of multi-stakeholder dialogues are not symmetrically developed across various stakeholders.

The core finding of the study is that the styles and approaches of multi-stakeholder communications have a strong impact on the diversity of the participants in collaborative governance. The fact that there are irregular and informal communication systems that are characterized by the absence of equal emphasis for responsible stakeholders and strong pre-dialogue procedures of communications resulted in the lack of diversity in collaborative water governance activities. To put it in a different context, collaborative governance activities, such as supervision of river sites, preliminary river assessment activities, regular river evaluation programs, the sharing of feedback and the sharing of resources, are affected by the level of mutual understanding, dialogues, and sharing of knowledge across various stakeholders.

The procedures and structures of dialogues have a significant impact on water governance activities. Instituting the principles of pre-deliberation forums to elicit curiosity, sense of engagement, and responsibility among the stakeholders is instrumental in developing thick deliberation programs. The absence of pre-deliberation communication procedures and structures across the stakeholders has led to the assumption that water governance is the responsibility of a few sectors alone. 
The representation of stakeholders by individuals that do not have the required knowledge and experience has a strong impact upon the collaboration of stakeholders in the implementation of water governance frameworks. The study found out that because most stakeholders are represented by individuals who have no strong experience and water-related knowledge, the multi-stakeholder process of producing quality water governance frameworks is affected. Therefore, since water problems have a multitude of contexts, knowledge production has to be from the ecological, social, business, education, construction, community, and political perspectives. However, in the study area, it was found out that water governance frameworks are limited by the absence of diversified knowledge from varying perspectives on account of limited involvement of stakeholders.

The exclusion and the lack of involvement of various stakeholders in multi-stakeholder dialogues prevent the establishment of a stable and socially legitimate water governance framework at various water sites. Since dialogues that do not combine the ideas of various stakeholders are deficient in articulating the interests of the various stakeholders, the implementation of action plans is limited in scope. This is because of the fact that the missing of the interests and knowledge of stakeholders creates a discrepancy between what is sociopolitically demanded and what is implemented. Water governance is mostly context-independent. Therefore, the participation of stakeholders is indispensable in creating a harmonious and acceptable water governance framework that could be implemented effectively and efficiently.

The policy implication of this study is that establishing a better and improved system of collaborative governance among stakeholders has to consider individual and institutional identities. To draw a shared motivation and combine various energies and resources, the pyramid of governance processes has to be abandoned. Then, a research-based, legally supported, culturally based, and the politically architected platform has to be created to unleash the potential of both persons and organizations in the governance of urban water projects.

Since this study does not show the political and policy aspects of collaborative water governance, it calls for further studies to understand the underlying political ontology that affects water governance. This paves the way for understanding the factors that influence the collaboration of stakeholders. Besides, to institutionalize collaboration, it is critical to focus on policy approaches both at micro- and macro-levels.

Acknowledgements The author is grateful to different individuals who provided a fountain of inspiration to engage in such research activity. I am so much indebted to Hailu Belay (Ph.D.) and Filmon Haddaro (Ph.D.) for their consistent and cooperative engagement in providing worthwhile feedbacks during the preparation of this study. Besides,
Meti Tamrat and Debela have also been cooperative in providing all the necessary data for the study.

Open Access This article is licensed under a Creative Commons Attribution 4.0 International License, which permits use, sharing, adaptation, distribution and reproduction in any medium or format, as long as you give appropriate credit to the original author(s) and the source, provide a link to the Creative Commons licence, and indicate if changes were made. The images or other third party material in this article are included in the article's Creative Commons licence, unless indicated otherwise in a credit line to the material. If material is not included in the article's Creative Commons licence and your intended use is not permitted by statutory regulation or exceeds the permitted use, you will need to obtain permission directly from the copyright holder. To view a copy of this licence, visit http://creativecommons.org/licenses/by/4.0/.

\section{References}

Abers R (2007) Organizing for governance: building collaboration in Brazilian River Basins. World Development 35(8):1450-1463. https://doi.org/10.1016/j.worlddev.2007.04.008

Addis Ababa Rivers Riversides Climate Change Adaptation Project Office (2017a) Addis Ababa Rivers and riversides management board discussion report

Addis Ababa Rivers Riversides Climate Change Adaptation Project Office (2017b) 100 K.M. 100 meter river cleaning rally project discussion paper

Agranoff R (2006) Inside collaborative networks: ten lessons for public managers. Public Adm Rev. file:///D:/saba/wrred/andsbg/ Hid_j.1540-6210.2006.00666.x.pdf

Alfredo K, Montalto F, Bartrand T, Wolde-Georgis T, Lall U (2016) Using a participatory stakeholder process to plan water development in Koraro. Ethiopia. Water 8:275

Ansell C, Gash A (2007) Collaborative governance in theory and practice. J Public Adm Res Theor 18(4):543-571. https://doi. org/10.1093/jopart/mum032

Arsano Y, Mekonnen E, Gudisa D, Achiso D (2010) Governance and drivers of change in ethiopia's water supply sector. A study conducted by the Organisation for Social ScienceResearch in Eastern and Southern Africa (OSSREA) in collaboration with the Overseas Development Institute (ODI)

Azadi H, Hafni P, Zarafshani E, Witlox F (2011) Multi-stakeholder involvement and urban green space performance. J Environ Plan Manag 54(6):785-811

Bogdan R, Biklen S (1998) Qualitative research for education. Allyn \& Bacon, Needham Heights

Braun V, Clarke V (2006) Using thematic analysis in psychology. Qual Res Psychol 3(2):77-101

Bryson JM, Crosby BC, Stone MM (2015) Designing and implementing cross-sector collaborations: needed and changing. Public Adm Rev 75:647-663

Della Porta D, Diani M (2005) Social movements: an introduction. Blackwell, Malden

Emerson K, Nabatchi T, Balogh S (2011) An Integrative framework for collaborative governance. J Public Adm Res Theory 54(4):768781. https://doi.org/10.1093/jopart/mur011

Environmental Protection Authority of Addis Ababa City (2008) Preliminary survey of pollution load on Akaki River, Little Akaki and Kebena River. Unpublished report, Addis Ababa, Ethiopia

Environmental Protection Authority of Addis Ababa City (2017) Quarterly report on river protection and conservation activities. Unpublished report, Addis Ababa, Ethiopia 
Eppel E (2014) Governance of a complex system: water. Working paper submitted to the Institute for Governance and Policy Studies

Franzén F, Hammer M, Balfors B (2015) Institutional development for stakeholder participation in local water management - an analysis of two Swedish catchments. J Land Use Policy 43(2015):217-227. https://doi.org/10.1016/j.landusepol.2014.11.013

Harrington C (2017) The political ontology of collaborative water governance. Water Int 42(3):254-270. https://doi.org/10.1080/02508 060.2017.1309507

Hermansa C, Ericksonb J, Noordewierc T, Sheldond A, Kline M (2007) Collaborative environmental planning in river management: an application of multi-criteria decision analysis in the White River Watershed in Vermont. J Environ Manag. https:// doi.org/10.1016/j.jenvman.2006.07.013

Holt A, Moug P, Lerner D (2012) The network governance of urban river corridors. Ecol Soc 17(4):25. https://doi.org/10.5751/ ES-05200-170425

Huntjens P, Louis L, Brian F (2015) The effectiveness of multi stakeholder dialogues on water. Working paper no. 10. http://www. thehagueinstituteforglobaljustice.org. Accessed 23 Dec 2018

Huxham S, Chris H, Vangen C, Eden C (2000) The challenge of collaborative governance, public management. Int J Res Theory 2(3):337-358

Leta S, Lema E, Alemu T, Abate Z, HaileMariamm H, Mekonnen A, Sahle M, Teshome G, Regassa CA (2016) Addis Ababa City rivers pollution and sanitation studies project. Unpublished Report, Addis Ababa, Ethiopia

Marie C, Rob C (2016) Power in collaborative approaches to governance for water: a systematic review. Soc Nat Resour 29(7):775790. https://doi.org/10.1080/08941920.2015.1080339

Megdal S, Eden S, Shamir E (2017) Water governance, stakeholder engagement, and sustainable water resources management. Water 9:190. https://doi.org/10.3390/w9030190

Meklit D, Mehammed A, Nuri M, Jemal A, Teshome N, MeseretM (2017) River assessment on Akaki River pollution and solid and liquid waste. Report to Addis Ababa Environmental Protection Authority

Morse R, Stephens J (2006) Teaching collaborative governance: phases, competencies, and case-based learning. J Public Aff Educ 18(3):565-583

Mutondo J, Farolfi S, Dinar A (2016) Water governance decentralization in Sub-Saharan Africa: between myth and reality. Springer, Cham. https://doi.org/10.1007/978-3-319-29422-3

O'Flynn J, Wanna J (2008) Collaborative governance: a new era of public policy in Australia. The Australian National University
Press, Australia. http://epress.anu.edu.au/collab_gov_citation. html. Accessed 20 May 2019

O'Leary R (2014) Collaborative governance in New Zealand: important choices ahead. Fulbright New Zealand. file:///D:/saba/wrred/ andsbg/Hid_axford2014_oleary.pdf

Olagunju A, Thondhlana G, Chilima JS, Sène-Harper A, Compaoré WN, Ohiozebau E (2019) Water governance research in Africa: progress, challenges and an agenda for research and action. Water Int 44(4):382-407. https://doi.org/10.1080/02508060.2019.1594576

Olsson L, Head W (2015) Urban water governance in times of multiple stressors: an editorial. Ecol Soc 20(1):27. https://doi.org/10.5751/ ES-07300-200127

Opperman J, Galloway G, Fargione J, Mount F, Richter B, Secchi S (2009) Sustainable floodplain through large-scale reconnection to rivers. Science 326:1487-1488

Organization for Economic Cooperation and Development (2015) Stakeholder engagement for inclusive water governance, OECD studies on water. OECD Publishing, Paris. https://doi. org/10.1787/9789264231122-en

Pahl-Wostl C, Ross A (2010) Finding general patterns in complex water governance regimes. J Reg Environ Change 10:261-262. https:// doi.org/10.1007/s10113-010-0150-4

Pahl-Wostl C, Craps M, Dewulf A, Mostert E, Tabara D, Taillieu T (2007) Social learning and water resources management. Ecol Soc 12(2):5

Porten SV (2013) Collaborative environmental governance and indigenous governance: a synthesis. University of Waterloo, Waterloo

Reynaud A, Markantonis V, Moreno C, M'Po Y, Sambienou G, Adandedji F, Afouda A, Agbossou E, Mama D (2015) Combining expert and stakeholder knowledge to define water management priorities in the MékrouRiver Basin. J Water 7:7078-7094. https ://doi.org/10.3390/w7126675

Schneider F, Bonriposi M, Graefe O, Herweg K, Homewood C, Huss M (2015) Assessing the sustainability of water governance systems: the sustainability wheel. J Environ Plan Manag 58:1577-1600

Woldesenbet W (2018) Collaborative governance: assessing the problem of weak cross-sectoral collaborations for the governance of Addis Ababa Rivers. Appl Water Sci. https://doi.org/10.1007/ s13201-018-0763-1

Publisher's Note Springer Nature remains neutral with regard to jurisdictional claims in published maps and institutional affiliations. 